\title{
Pooling data on different probiotics is not appropriate to assess the efficacy of probiotics
}

\author{
Hania Szajewska
}

Received: 29 December 2013 / Revised: 25 January 2014 / Accepted: 30 January 2014 / Published online: 22 May 2014

(C) The Author(s) 2014. This article is published with open access at Springerlink.com

Dear Editor,

Li et al. [2] presented the pooled results of randomized controlled trials and concluded that probiotic administration increases the $H$ pylori eradication rate and reduces the risk of therapy-related side effects.

It is tempting to produce a single estimate of the treatment effect of probiotics. However, pooling data from different strains and doses of probiotics obtained in different settings and/or populations may result in misleading conclusions. The risk is that the results could be erroneously extrapolated to other probiotics. This concern is shared by many experts in the field of probiotics $[1,3,4]$.

In settings where there are tens of different probiotic products available, one wants to know the efficacy of one specific probiotic, not of probiotics in general. The meta-analysis by $\mathrm{Li}$ et al. does not help to resolve such uncertainty.

What could be the solution? One approach could be to perform a meta-analysis that evaluates the effect of administering a clearly defined, probiotic(s). In children, for there is no single probiotic that has been studied in more than one RCT. With a lack of repeat studies, can we be sure that all or any probiotic(s) studied are really effective?

In my opinion, those of us who are working in the probiotic field should avoid pooling data on different probiotics.

Conflict of interest HS declares no financial support from any organization for the submitted work.
Open Access This article is distributed under the terms of the Creative Commons Attribution License which permits any use, distribution, and reproduction in any medium, provided the original author(s) and the source are credited.

\section{References}

1. Agostoni C, Buonocore G, Carnielli VP, De Curtis M, Darmaun D, Decsi T, Domellöf M, Embleton ND, Fusch C, Genzel-Boroviczeny O, Goulet O, Kalhan SC, Kolacek S, Koletzko B, Lapillonne A, Mihatsch W, Moreno L, Neu J, Poindexter B, Puntis J, Putet G, Rigo J, Riskin A, Salle B, Sauer P, Shamir R, Szajewska H, Thureen P, Turck D, van Goudoever JB, Ziegler EE, ESPGHAN Committee on Nutrition (2010) Enteral nutrient supply for preterm infants: commentary from the European Society of Paediatric Gastroenterology, Hepatology and Nutrition Committee on Nutrition. J Pediatr Gastroenterol Nutr 50:85-91

2. Li S, Huang XL, Sui JZ, Chen SY, Xie YT, Deng Y, Wang J, Xie L, Li TJ, He Y, Peng QL, Qin X, Zeng ZY (2013) Meta-analysis of randomized controlled trials on the efficacy of probiotics in Helicobacter pylori eradication therapy in children. Eur J Pediatr. 2013 Dec 10. [Epub ahead of print] PubMed PMID: 24323343.

3. Rijkers GT, Bengmark S, Enck P, Haller D, Herz U, Kalliomaki M, Kudo S, Lenoir-Wijnkoop I, Mercenier A, Myllyluoma E, Rabot S, Rafter J, Szajewska H, Watzl B, Wells J, Wolvers D, Antoine JM (2010) Guidance for substantiating the evidence for beneficial effects of probiotics: current status and recommendations for future research. J Nutr 140:671S-6S

4. Szajewska H, Guarino A, Hojsak I, Indrio F, Kolacek S, Shamir R, Vandenplas Y, Weizman Z (2014) Use of probiotics for management of acute gastroenteritis: a position paper by the ESPGHAN Working Group for Probiotics and Prebiotics. J Pediatr Gastroenterol Nutr 58:531-539
Communicated by Peter de Winter

H. Szajewska $(\bowtie)$

Department of Paediatrics, The Medical University of Warsaw,

Dzialdowska 1, 01-184 Warsaw, Poland

e-mail: hania@ipgate.pl 